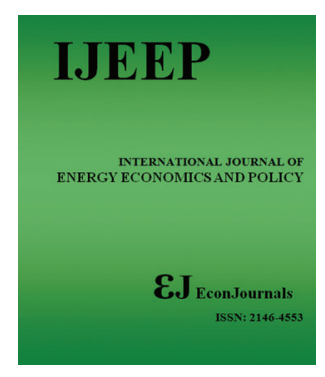

International Journal of Energy Economics and
Policy

ISSN: $2146-4553$

available at http: www.econjournals.com

International Journal of Energy Economics and Policy, 2020, 10(2), 529-539.

\title{
Energy Consumption, Economic Growth and Environmental Degradation in 4 Asian Countries: Malaysia, Myanmar, Vietnam and Thailand
}

\author{
Phrakhruopatnontakitti ${ }^{1}$, Busakorn Watthanabut ${ }^{2}$, Kittisak Jermsittiparsert ${ }^{3 *}$
}

${ }^{1}$ Faculty of Education, Mahachulalongkornrajavidyalaya University, Ayutthaya, Thailand, ${ }^{2}$ Faculty of Liberal Arts, North Bangkok University, Pathumthani, Thailand, ${ }^{3}$ Contemporary Peasant Society Research Unit, Social Research Institute, Chulalongkorn University, Bangkok, Thailand.*Email: kittisak.j@chula.ac.th

\begin{abstract}
This paper examines dynamic causal relationships between pollutant emissions, energy consumption and output for a panel of 4 Asian (MMVT) countries over the period 1971-2005, except for Vietnam (1990-2005). In long-run equilibrium energy consumption has a positive and statistically significant impact on $\mathrm{CO}_{2}$ emissions. In the short term, changes in emissions are driven mostly by the error correction term and short term energy consumption shocks, as opposed to short term output shocks for each country. Short-term deviations from the long term equilibrium take from 0.77 years (Myanmar) to 4.84 years (Malaysia) to correct. The panel causality results indicate there are energy consumption-emissions bidirectional strong causality and energy consumption-output bidirectional long-run causality, along with unidirectional both strong and short-run causalities from emissions and energy consumption, respectively, to output. Overall, in order to reduce $\mathrm{CO}_{2}$ emissions and not to adversely affect economic growth, increasing energy supply investment and energy efficiency, and stepping up energy conservation policies to reduce unnecessary wastage of energy can be initiated for energy-dependent MMVT countries.
\end{abstract}

Keywords: $\mathrm{CO}_{2}$ Emission, Error Correction Model, Malaysia, Myanmar, Vietnam and Thailand

JEL Classifications: Q2, Q4

\section{INTRODUCTION}

The one of the essential engines of monetary development is energy consumption, and the energy utilization is related with an increase in $\mathrm{CO}_{2}$ emissions. Current studies, has more focused on the causality relation between environmental degradation, energy consumption and economic growth, as connected them with other indicators such as financial development, foreign direct investment (FDI) or trade openness (Keppler and Mansanet-Bataller 2010; Pao and Tsai, 2011; Ozturk and Acaravci, 2013). Meanwhile, in both the developed and developing economies the agriculture is always an important determinant of the economies. Environmental troubles particularly, the growth in earth temperature and change in climates has become more interest. Increase in world ocean temperatures and average air, extensive melting of ice and snow, and growing international standard ocean degree are a few evidences of international warming. The predominant greenhouse fuel is $\mathrm{CO}_{2}$ emission, which is a international pollutant that causes $58.8 \%$ of worldwide warming and weather alternate (Bank 2007).

Dantama, Abdullahi et al. (2012), estimated electricity impacts all aspects of development containing monetary, social or even first-rate of lifestyles. Energy is likewise tested as an essential detail in the industrialization and advances generation Jumbe (2004). It became also determined that the multiplied in strength consumption indicates the high financial repute of a country, as 
well as its function in fostering the productivity of exertions, capital, and different elements of manufacturing. Energy can be disaggregated into multiple elements which include oil, gas, energy, and coal. However, among those forms of strength, oil appears to be the maximum frequently used proxy for power within the past studies to decide economic growth both by means of thinking about the charge or the intake of the power itself, for example, (Masih and Masih (1996), Asafu-Adjaye (2000), Ozturk et al. (2010); Lau et al., (2011); Dahmardeh et al. (2012)). Even though many researches on energy economics use oil becomes as a proxy for energy, energy is also regarded as an amazing fine strength element as it helps a wide range of services and products that encourage increase in growth, Adom (2011). Excluding, oil projected as the slowest developing power for the next two decades Finley (2012). In recently, researchers carried out studies on the causality relation among economic growth and energy consumption. The effects are unique in all of the nation's deliberate. Indonesia has a causal one way relation among energy consumption and economic growth, Hwang and Yoo (2014). For some extra studies, it's miles that there is no causative relation among economic growth and energy consumption in Greece, Netherlands, Sweden, Spain, France, Italy and Portugal Xue et al. (2014). Some estimations have revealed two way causative relation between economic growth and energy consumption in India(Paul and Bhattacharya 2004) and Sri Lanka (Morimoto and Hope 2004).

Energy is an essential branch of the long term energy accessibility hypothesis which could change economic growth Stern (2011). Malaysia has high rates of energy consumption Due to the servicebased and manufacturing economy in Malaysia, (Lean and Smyth 2014). As related by Lean and Smyth (2014), Islam et al. (2009) and Bari, Yusuff et al. (2012), the energy demand had increased rapidly in the past three years in Malaysia. The demand for energy in industry was increasing for above than $300 \%$ from 1985 to 2015 this status is steady with the information in Malaysia energy records Hub. Hence, it is very clear evidence that there is an increasing growth in demand for energy in Malaysia. In Malaysia, there is very high economic growth, especially in the industry region involvement changed into approximately $38 \%$ of the entire GDP in 2016 Bank (2017). Malaysia is strongly dependent on fossil fuels. Unfavorably, Malaysia's confirmed natural gas reserves and oil are projected to be exhausted within the future 19 and 33 years, correspondingly if different measures are not revealed to maintain the reserves, Yusoff and Bekhet (2016). According, (Oh, Pang et al. 2010) also recognized that Malaysia becomes a nation of net oil importer through the year 2030. This scenario shows Malaysia to discover a different energy sources to replace the fossil fuels.

Vietnam is a one of the very fastest developing growing economies in Asia; it's mean around 7.1\% annual GDP growth from 2006$2009,6.8 \%$ in 2010 , and $6.0 \%$ in 2011 . However, rapid economic growth is usually accompa-nied by increase in energy consumption and may create unexpected results on environment and energy assets. Vietnam's energy intake became four times higher in 2010 than its consumption in 1980, growing from 14.39.
The impact of economic growth on environmental-pollutants, in addition to economic growth and energy consumption, has been purposefully examined experimentally during the last twenty years. Though, they found results remain argumentative and inconclusive to this point. The first catena is associated with testing the effectiveness of the Environmental Kuznets Curve speculation. The Environmental Kuznets Curve speculation estimates the impact of financial improvement on environment seems as an U shape inverted curve Ang (2007). It implies environmental-pollutants level growth as a rustic develop; however provoke to reduce as growing earning exceed faraway from a turning point. The Environmental Kuznets Curve (EKC) speculation became first determined and proved via Grossman and Krueger (1991). Dinda (2004) and Stern (2004) present analysis research of these findings. moreover these cases are consistent with Managi and Jena (2008), Dinda and Coondoo (2006), Martínez-Zarzoso and Bengochea-Morancho (2004) and Friedl and Getzner (2003). Though, greater country wide income does not always allow better efforts to keep the $\mathrm{CO}_{2}$ emissions pollutants. Recently, Lee and Lee (2009) and Coondoo and Dinda (2008) offer evaluation of time series among income and $\mathrm{CO}_{2}$ to interpret the causality-path. The experimental findings arise to be indeterminate. The $2^{\text {nd }}$ point is relevant to the growth and energy consumption link. This link shows that GDP and energy intake each are can be collectively expected, because better economic development calls for higher energy intake. In the same way, more energy uses need a more plane of economic-development. However, the causality route might not be predicted earlier. subsequent the fundamental study by Kraft and Kraft (1978), offer growing some studies have determine the observational records by means of the use of Granger causality and cointegration models. The modern-day research encompass the ones by (Pao, 2009), (Belloumi 2009), (Narayan and Prasad, 2008; Narayan et al., 2008) and (Mehrara 2007).

In Accordance to the World Bank, GDP consistent with a country per capita is assessed into four classes: higher middle income, High earnings (GDP consistent with 12476 USD per capita or extra), low income (GDP in line with 1025 USD per capita or much less) and lower middle income (GDP consistent with 1026 USD-4035 USD per capita). According to given category, there are 4 ASEAN nations that commonly represent the upper middle income countries are Malaysia and Thailand, Singapore is a high income country, and Myanmar and Vietnam are the lower middle income countries.

Various studies related to the connection with economic growth and $\mathrm{CO}_{2}$ emissions Alam, Murad et al. (2016); Rezitis and Ahammad (2015); Abidin, Haseeb et al. (2015); Al Mamun, Sohag et al. (2014); Magazzino (2014). The each of the country studies has different results. There is a one way causative linkage among GDP growth and $\mathrm{CO}_{2}$ emissions in France, Ang (2007) Pakistan Shahbaz et al. (2012), Bangladesh Alam, Begum et al. (2012) and South-Africa Menyah and Wolde-Rufael (2010). For some another findings, there may be no causative linkage between economic growth and $\mathrm{CO}_{2}$ emissions in Turkey Ozturk and Acaravci (2010) and the United States Soytas et al. (2007). Some another findings have determined a two way causative linkage between economic 
growth and $\mathrm{CO}_{2}$ emissions in India and Brazil (Pao and Tsai, 2011), South Korea (Kim et al. 2010).

The organization of this study is as following parts. Part 2 Data. Part 3 model and methodology. Part 4 provides the estimated results. Part 5 presents a final section discussion and polices, with concluding remarks.

\section{DATA}

Panel data is accumulated for 4 Asian nations from the WDI on their $\mathrm{CO}_{2}$ emissions, real GDP and energy use over the duration 1971-2005, besides for Vietnam (1990-2005). Per capita $\mathrm{CO}_{2}$ emissions are measure by using the flaring of fossil fuels and consumption. Per capita energy use is measured in oil-kg and Per capita real GDP is measured in 2010 US constant dollars. Table 1 gives a summary statistics without taking logarithm of three variables for every country. Myanmar having the very best in keeping with capita emissions approach (11.996) and energy use (4678.81), with the very high mean of real GDP per capita (3513.30) is in Malaysia. The very low mean of emissions per capita (1.048), energy use (428.80) and real-GDP (320.27) are in Vietnam. Myanmar has the very high variation in per capita emissions by the standard deviation (1.738), energy use (512.23) and real-GDP (236.23), even as Vietnam has the lowest variation in all variables. According to, for 4 Asian countries, Myanmar having the very high mean and variance of per-capita $\mathrm{CO}_{2}$ emissions and energy use, even as the very low mean and variance for per-capita $\mathrm{CO}_{2}$ emissions, output and energy use is in Vietnam.

The Table 2 represents the growth-rates in percentage for all variables of MMVT (Malaysia, Myanmar Vietnam, and Thailand) countries. Five-year, ten-year and fifteen-year growth rates are estimated similar to growth between the years 1990 to 2005,1995 to 2005 and 2000 to 2005 . Thailand had the very high fifteen (year), ten (year), and five (year) growth-rates in per-capita emissions $(4.78 \%, 4.83 \%$, and $9.99 \%)$, energy use $(3.74 \%, 4.25 \%$, and $8.54 \%)$ and real GDP $(9.13 \%, 8.24 \%$, $8.88 \%$ ). Malaysia had the minimum growth-rates in the recent five-years (2000to2005), in per capita $\mathrm{CO}_{2}$ emissions $(0.18 \%)$, energy use $(1.28 \%)$ and real- GDP(1.34\%), which became in the world less than the growth rates for all variables. The data for these studies are to be had beginning from 1971, besides for Vietnam beginning from 1990 and Vietnam behave otherwise than the opposite three international locations, this studies makes use of panel statistics for the analysis both unbalanced MMVT and balanced MMT (Malaysia, Myanmar and Thailand) international locations. The MMT evaluation is completed as a check of robustness. For modeling purposes, to accomplishing the empirical estimation the data has been transformed into $\log$ form.

\section{THE MODEL AND METHODOLOGY}

\subsection{The Model}

The findings of studies in energy-economics, its miles logical within the long run relation among $\mathrm{CO}_{2}$ emissions, energy consumption and economic growth in linear logarithmic quadrate form with a vision of proofing the effectiveness of the Environmental Kuznets curve hypothesis (EKC) by way of the usage of panel statistics structure as follows:

$$
L C O i t=\beta o i+\beta 1 i L E C i t+\beta 2 i L G D P i t+\beta 3 i L G D P 2 i t+\varepsilon i t
$$

Here $t=1, \mathrm{~T}$ indicates the time-period and $i=1, \mathrm{~N}$ indicates the country. The natural logaritham of the variables $\mathrm{CO}_{2}$ emission, total energy consumption and real GDP represents by employing the LCO, LEC and LGDP, respectively. The energy consumption anticipated has advantageous signal because a better degree of energy consumption must result in higher degree of economic

Table 1: Summary statistics, 1990-2005 (without taking log)

\begin{tabular}{|c|c|c|c|c|c|c|}
\hline & \multicolumn{2}{|c|}{$\mathrm{CO}_{2}$ emission } & \multicolumn{2}{|c|}{ Energy-use } & \multicolumn{2}{|c|}{ RealGDP } \\
\hline & Mean & Standard deviation & Mean & Standard deviation & Mean & Standard deviation \\
\hline Malaysia & 1.523 & 0.150 & 1142.34 & 66.43 & 3513.30 & 182.60 \\
\hline Myanmar & 11.996 & 1.738 & 4678.81 & 512.23 & 1836.81 & 236.23 \\
\hline Vietnam & 1.048 & 0.137 & 428.80 & 34.07 & 320.27 & 73.71 \\
\hline Thailand & 3.662 & 0.487 & 912.07 & 150.7 & 734.004 & 334.62 \\
\hline
\end{tabular}

Table 2: Average growth-rates for $\mathrm{CO}_{2}$ emissions, energy-use and real GDP (prior to taking log) 1990 to2005

\begin{tabular}{|c|c|c|c|c|c|}
\hline & Malaysia & Myanmar & Vietnam & Thailand & The world \\
\hline \multicolumn{6}{|c|}{ Panel A: $\mathrm{CO}_{2}$ emissions, in metrictons per-capita } \\
\hline 15 year growth & 1.73 & 2.34 & 3.18 & 4.78 & 0.36 \\
\hline 10 year growth & 1.24 & 0.25 & 2.65 & 4.83 & 0.92 \\
\hline 5 year growth & 0.18 & 1.28 & 2.26 & 9.99 & 2.17 \\
\hline \multicolumn{6}{|c|}{ Panel B: Energy use, equivalent oil in k.g per-capita } \\
\hline 15 year growth & 1.51 & 1.72 & 1.78 & 3.74 & 0.43 \\
\hline 10 year growth & 1.47 & 0.66 & 1.68 & 4.25 & 0.91 \\
\hline 5 year growth & 1.28 & 1.66 & 1.76 & 8.54 & 1.48 \\
\hline \multicolumn{6}{|c|}{ Panel C: Real-GDP US \$2000 per-capita } \\
\hline 15 year growth & 1.24 & 0.52 & 4.29 & 9.13 & 1.41 \\
\hline 10 year growth & 0.87 & 4.31 & 4.81 & 8.24 & 1.71 \\
\hline 5 year growth & 1.34 & 6.70 & 5.29 & 8.88 & 1.48 \\
\hline
\end{tabular}


activity. According to the EKC hypothesis, the expected coefficient for $\beta_{2}$ is to be positive, where the expected coefficient for $\beta_{3}$ is a negative. If results shows the LGDP is statistically-insignificant, it indicates the linkage among per-capita $\mathrm{CO}_{2}$ emissions and per-capita income in a monotonic increase(Halicioglu, 2009). The stochastic term indicates by $u$ it is assumed to be errors are impartial and randomly distribute and its mean is zero and variance is constant.

\subsection{Cointegration Methodology}

The existences of a long run relation some variables are within the empirical analysis, we test for evaluation of Equation 1 at the same time as the ECM (Error-Correction-Model) takes the variables shortrun effects. There are three steps for estimation of the results. The $1^{\text {st }}$. step is to check the variables integration-order due to the co-integration assessments is in general applicable when order of integration is same for all the variables. The panel unit-root tests has four types, Im, Pesaran et al. (2003), Levin et al. (2002), Breitung (2001), and Fisher kinds of tests the usage of AugmentedDickey Fuller (FADF) (Choi 2001) (Maddala and Wu 1999);, are applied.

$2^{\text {nd }}$-step is, while all variables has same order of integration, the Johansen Fisher (Kao 1999; Maddala and Wu 1999; Pedroni 1999, 2004) techniques are applied to check the co-integration relation in panel. Engle and Granger (1987) Two step of tests cointegration encompass Kao and Pedroni assessments, for testing no co-integration of null hypothesis in different panels Pedroni provides statistics are seven. These tests may be categorized as panel tests (within dimension) or group tests (between dimensions). These all tests are depend on errors from Eq1 and are alternatives of the augmented dickey-fuller are Phillips and Perron (1988) tests. The Kao-test indicates cross-section particular intercept and same co-efficient throughout the firststage, this test comply the fundamental approach similar as the Pedroni-tests. The test of Fisher is a combination of Johansen and Juselius (1990)-test. In case the variables are co-integrated, ordinary lest square (OLS) is implemented to ensure that the estimation of equation. 1 doesn't have spurious-regression results. The variables determined by ordinary lest square are highly consistent (Alves and da Silveira Bueno 2003). The consumption coefficients in long run energy are $\beta_{1}, \beta_{2}$ and $\beta_{3}$, real-GDP and $G D P^{2}$, correspondingly.

The final step, if all variables are included stationary at first difference and co-integrated, following Masih and Masih (1996), short run effects can be predicted by the Vector-Errors-Correction-model(VECM) recommended through using Engle and Granger (1987). within this technique, results of co-integration among the collection of variables manner so that there is exists a Error-Correction-Mechanism through such adjustments inside the established variables are modelled like a feature of the dis-equilibrium level within the co-integrating relation, capture via the ECT, in addition to adjustments inside the different independent variables to captured all short term linkage amongst variables. The Vector Error Correction Model (VECM) is constructed, for one country as follow:

$$
\begin{aligned}
& \Delta L C O_{t} \gamma_{o+} \sum_{j=1}^{p 1} \gamma_{1 j} \Delta L C O_{t-j}+\sum_{j=0}^{p 2} \gamma_{2 j} \Delta L E C_{t-j} \\
& +\sum_{j=0}^{p 3} \gamma_{3 j} \Delta L G D P_{t-j}+\sum_{j=0}^{p 4} \gamma_{4 j} \Delta L G D P_{t-j}^{2}+\lambda E C T_{t-1}+V_{t}
\end{aligned}
$$

Where $\mathrm{ECT}_{\mathrm{t}}=\mathrm{LCO}_{\mathrm{t}}-\beta_{\mathrm{o}}-\beta_{1} \mathrm{LECT}_{\mathrm{t}}-\beta_{2} \mathrm{LGDP}_{\mathrm{t}}-\beta_{3} \mathrm{LGDP}_{\mathrm{t}}^{2}$.

Here $\mathrm{t}=1$ and the time-period indicates by $\mathrm{T}$, optimal-lag denotes by $p i$ the estimated through the Schwarz-Bayesian-criterion(SBC), and $v_{t}$ is unrelated error-term. The More specification of the version, the ECT indicates the Error-Correction Term, and the sign $\lambda$ is provide an explanation for to be the speed of adjustment for all shocks main to version equilibrium in the long run. The Vector Error Correction Model (VECM) indicates each equilibrium in long run (with the aid of co-integration) and short run equilibrium (with the aid of changes in explanatory variables). Estimations for these models are OLS method of regression and the normality-tests for errors are estimated through the Jarque-Bera (J-B) (Jarque and Bera 1980) facts.

\subsection{Granger Causality}

Error Correction Model (ECM) and Vector Auto Regression(VAR) are frequently employed to explore the granger-causation among the variables. If all variables are at first difference order I.(1) by means of no cointegration, a vector auto regression in order of first differences the variables might be proceeded. If all variables had been to be co-integrated then Error Correction Model can be performed. The Vector Auto Regressive technique aimed by Toda and Yamamoto (1995) (there after T-Y) can be used for every autocratic degree of co-integration. It cannot entail awareness on co-integration. If instability exist then the same as to unless the variables are at level or first difference, VAR method is become conducted on the secure area (Zapata and Rambaldi 1997). The VAR technique is not appropriate in this article due to the fact each and every one variables are at first difference I(1) in Equation.1.

The presence of co-integration proved that here is association amongst the variables in at-least single long run equilibrium, and at least single direction Granger causality among them Oxley and Greasley (1998);Engle and Granger (1987). For improving disequilibrium in the cointegration association VECM is used, taken by the ECT, moreover long run and short run causality check amongst co-integrated variables. For panel causality take a look at, panel primarily based Vector Error Correction Model is as follow:

$$
\begin{aligned}
& \Delta L C O_{i t}=\alpha_{1 i}+\sum_{j=1}^{p 11} \beta_{11 i j} \Delta \mathrm{LCO}_{\mathrm{it}-\mathrm{j}}+\sum_{j=1}^{p 12} \beta_{12 i j} \Delta L E C_{i t-j} \\
& +\sum_{j=1}^{p 13} \beta_{13 i j} \Delta L G D P_{i t-j}+\sum_{j=1}^{p 14} \beta_{14 i j} \Delta \mathrm{LGDP}_{\mathrm{it}-\mathrm{j}}^{2}+\theta_{1 \mathrm{i}} E C T_{i t-1}+\varepsilon_{1 i t} \\
& \Delta L E C_{i t}=\alpha_{2 i}+\sum_{j=1}^{p 21} \beta_{21 i j} \Delta \mathrm{LCO}_{\mathrm{it}-\mathrm{j}}+\sum_{j=1}^{p 22} \beta_{22 i j} \Delta L E C_{i t-j} \\
& +\sum_{j=1}^{p 23} \beta_{23 i j} \Delta L G D P_{i t-j}+\sum_{j=1}^{p 24} \beta_{24 i j} \Delta \mathrm{LGDP}_{\mathrm{it}-\mathrm{j}}^{2}+\theta_{2 \mathrm{i}} E C T_{i t-1}+\varepsilon_{2 i t}
\end{aligned}
$$




$$
\begin{aligned}
& \Delta L G D P_{i t}=\alpha_{3 i}+\sum_{j=1}^{p 31} \beta_{31 i j} \Delta \mathrm{LCO}_{\mathrm{it}-\mathrm{j}}+\sum_{j=1}^{p 32} \beta_{32 i j} \Delta L E C_{i t-j} \\
& +\sum_{j=1}^{p 33} \beta_{33 i j} \Delta L G D P_{i t-j}+\sum_{j=1}^{p 34} \beta_{34 i j} \Delta \mathrm{LGDP}_{\mathrm{it}-\mathrm{j}}^{2}+\theta_{3 \mathrm{i}} E C T_{i t-1}+\varepsilon_{3 i t} \\
& \Delta L G D P_{i t}^{2}=\alpha_{4 i}+\sum_{j=1}^{p 41} \beta_{41 i j} \Delta \mathrm{LCO}_{\mathrm{it}-\mathrm{j}}+\sum_{j=1}^{p 42} \beta_{42 i j} \Delta L E C_{i t-j} \\
& +\sum_{j=1}^{p 43} \beta_{43 i j} \Delta L G D P_{i t-j}+\sum_{j=1}^{p 44} \beta_{44 i j} \Delta \mathrm{LGDP}_{\mathrm{it}-\mathrm{j}}^{2}+\theta_{4 \mathrm{i}} E C T_{i t-1}+\varepsilon_{4 i t}
\end{aligned}
$$

Here $t=1$ and $T$ denote the time-period $i=1$ and $N$ denote the country, $\mathrm{p}_{\mathrm{ij}}$ shows the optimal lags estimated via the $\mathrm{SBC}$ (Schwarz Bayesian criterion), ECT (Error-Correction-Term) is exposed in Equation 2 and the error-term indicate by $e$ it is implicit that randomly distributed with a constant variance and zero mean. The WLS(Weighted Least Square) technique used for fixed-effects is employed for estimation of Equation.3; the various methods are accessible in E-Views for estimation of panel data. The Vector Error Correction Model applied for two causation sources: $1^{\text {st }}$ is short-run causality (lag dynamic term) or $2^{\text {nd }}$ is long-run causality (error correction term). In two causality sources, we be able to execute three dissimilar tests of causality, same as, short run no causality test, weak-erogeneity (long run no causality test) and tests for strong-erogeneity (Ang 2008).

In Equation 3, to check either real-output (growth) each in D-GDP and D-GDP ${ }^{2}$ cannot Granger cause energy-consumption (growth) or $\mathrm{CO}_{2}$ emissions in the shortrun growth, we estimate the lagged dynamic term of significance with the aid of the null hypothesis testing together $\beta_{13 i p}=, \beta_{14 i p}=0, \forall i p$ or $\beta_{23 i p}=, \beta_{24 i p}=0, \forall i p$ the use of the Wald-Test. The null hypothesis rejection shows that output-growth granger causes energy-consumption (growth) or emissions (growth), in the short run. The causal determination from whether D-LCO or D-LEC to output (growth) (D-LGDP and $\left.\mathrm{D}-\mathrm{GDP}^{2}\right)$, fractious equation limits can be conducted on Equations 3, 4. In case the null-hypotheses $\beta_{31 \text { ip }}=0, \forall i p$ and $\beta_{41 \text { ip }}=0, \forall i p$ are rejected then Short run Granger-causality from DLCO to real output is supportive, in case the null-hypotheses $\beta_{32 \mathrm{ip}}=0, \forall i p$ and $\beta_{42 \mathrm{ip}}=0, \forall i p$ are rejected then energy consumption to real output from causality is supportive Apergis and Payne (2009), (Masih and Masih (1996), Asafu-Adjaye 2000) explained dependent variable returns just to short-terms shocks to the random surroundings in fragile short run Granger causality.

The fragile exogeneity check of the structured variable, which is a perception of long run no causality check, implies pleasing the null-hypothesis $\theta_{1 i}=0 \forall i$ for noncausality equilibrium in long run divergence in the preceding duration to emissions. For no causality equilibrium in long run divergence to real output, this calls for null hypotheses of non-rejection $\theta_{3 i}=0 \forall i$ and $\theta_{4 i}=0 \forall i$. In Final, we will execute the dependent variable strong-exogeneity test, which impose more potent limitations through checking out thesignificance-jointly of each the lag dynamical conditions and Error Correction Term. This implies pleasing mutually Granger no causality and weak exogeneity. In precise, if the joint nullhypothesis $\beta_{13 i p}=\beta_{14 i p}=\theta_{1 i}=0 \forall i p$ is not rejected, the real-output growth does not Granger cause emissions growth, if the joint null hypotheses $\beta_{31 i p}=\theta_{3 i}=0 \forall i p$ and $\beta_{41 i p}=\theta_{4 i}=0 \forall i p$ are not rejected then the emissions-growth do not Granger cause realoutput-growth. This relation indicated to as strong granger causality tests Mehrara (2007), Mahadevan and Asafu-Adjaye (2007), Yoo (2005). Comparable reasons are possible for exploring either the real-output stronger granger cause energy-consumption. The jointly test specify certain variables accept the trouble of short run adjustments to reset up equilibrium in long run, as a result a shocks to the structure (Asafu-Adjaye 2000; Shiu and Lam 2004; Yoo, 2005; Yuan et al. 2007).

\section{ESTIMATED-RESULTS}

\subsection{The Panel Co-integration Tests and Panel Unit Roots Test}

In Equation 1 variables are examined by panel unit root tests of four types for balanced MMT and un-balanced MMVT (Malaysia, Myanmar and Thailand) panel-data, wherever the robustness check of MMT analysis can be used. The penal unit root testes FADF, LLC, IPS, and Breitung used a null hypothesis of a unit-root. The tests of FADF, LLC, IPS, and Breitung suppose that here is an individual's unit-root technique through cross-section, and the alternate-hypothesis is use without unit-root means stationary. Findings of Appendix A for MMT and Table 3 for MMVT shows that each and all variables in Equation 1 arise to restrain a unit root of panel for their degrees, yet stationary at first differences, that they are incorporated at first order of integration(1). The robust-ness of un-balanced unit-root panel test is examined through the findings of Appendix A.

The four variables are at first order of integration, the panel cointegration among $\mathrm{CO}_{2}$ emissions and other sporting variables are verified by tests of Kao, Pedroni and Fisher for balanced MMT and un-balanced MMVT panel-data, the findings of these panels are displayed in Table 4 and Appendix B. The findings of Pedroni test expose the null hypothesis rejections of no co-integration for

\begin{tabular}{|c|c|c|c|c|c|c|c|c|}
\hline & \multicolumn{2}{|c|}{ Liven-Lin-Chu } & \multicolumn{2}{|c|}{ Breitung } & \multicolumn{2}{|c|}{ Im-Pesarn-Shin } & \multicolumn{2}{|c|}{ FADF } \\
\hline & Level & First-diff & Level & First-diff & Level & First-diff & Level & First-diff \\
\hline L.CO & -0.03 & $-4.1 * * *$ & -0.1 & $-5.1 * * *$ & 0.07 & $-4.0 * * *$ & 7.9 & $39.5^{* * *}$ \\
\hline L.EC & -0.8 & $-4.3 * * *$ & -0.5 & $-5.1^{* * *}$ & -1.1 & $-4.0^{* * *}$ & 4.3 & $36.2^{* * *}$ \\
\hline L.GDP & -0.8 & $-3.2^{* * *}$ & 1.4 & $-3.3 * * *$ & 0.2 & $-5.0^{* * *}$ & 8.35 & $39.6^{* * *}$ \\
\hline L.GDP ${ }^{2}$ & -0.7 & $-3.7 * * *$ & 1.3 & $-3.9 * *$ & 0.9 & $-4.4 * * *$ & 6.1 & $41.9^{* * *}$ \\
\hline
\end{tabular}
each test at 5\% level or best significance level excluding for the group and panel R-tests and panel U-test. Hence, in accordance

Table 3: Unit root test results

The lag selection is base on SBC. *** indicates that the null-hypothesis rejection at $1 \%$ significance levels 
with Pedroni (2004), Pedroni three check statistics cannot rejected the null hypothesis might also have a extremely small down control inside the casing of little time proportion. The reality is likewise with Al-Iriani (2006). Consequently the variables in Equation 1 can conclude that are in reality co-integrated panel. The test of Kao also indicates co-integration in penal at $1 \%$ significance level. Similarly, Johansen-Fisher test indicates the presence of two vector cointegration at 5\% significance level. Generally $\mathrm{CO}_{2}$ emissions, GDP, GDP ${ }^{2}$ and energy consumption have strong statistical essentials in support of panel co-integration for MMVT countries. The identical findings are exposed in Appendix B for MMT countries. The cointegration equation of penal can be written as

$$
\begin{aligned}
& \mathrm{LCO}=-15.18+1.85 \mathrm{LEC}+1.35 \mathrm{LGDP}-0.12 \mathrm{LGDP}^{2} \\
& \quad(-14.4)^{* * *}(13.7) * * *(6.2) * * *(-6.7) * * *
\end{aligned}
$$

Wherever the statistics in brackets indicate standard-errors and

\begin{tabular}{|c|c|c|}
\hline \multicolumn{3}{|c|}{ Pedrono test } \\
\hline \multicolumn{3}{|l|}{ Test statistics } \\
\hline \multicolumn{3}{|l|}{ Panel v stat(weighted statistic) } \\
\hline Panel $\rho$ stat (weighted statistic) & \multicolumn{2}{|l|}{1.41} \\
\hline Panel PP stat (weighted statistic) & \multicolumn{2}{|l|}{$-1.67 * *$} \\
\hline Panel ADFstat (weighted statistic) & \multicolumn{2}{|l|}{$-1.97 * *$} \\
\hline Group $\rho . s t a t$ & \multicolumn{2}{|l|}{2.21} \\
\hline Group PP.stat & \multicolumn{2}{|l|}{$-7.61 * * *$} \\
\hline Group ADF.stat & \multicolumn{2}{|l|}{$-2.26 * *$} \\
\hline Kao-test & \\
\hline ADF.stat. & \multicolumn{2}{|l|}{$-3.20(0.00)^{* * *}$} \\
\hline \multicolumn{3}{|c|}{ Johansen-fisher test } \\
\hline Null hypothesis & $\begin{array}{l}\text { Maximum- } \\
\text { eigen.value }\end{array}$ & Trace.value \\
\hline $\mathrm{R}=0$ & $57.7(0.000)^{* * *}$ & $65.7(0.000)^{* * *}$ \\
\hline $\mathrm{R} \leq 1$ & $17.4(0.01)^{* *}$ & $21.5(0.007)^{* * *}$ \\
\hline $\mathrm{R} \leq 2$ & $11.3(0.24)$ & $8.01(0.35)$ \\
\hline $\mathrm{R} \leq 3$ & $4.5(0.89)$ & $4.5(0.89)$ \\
\hline
\end{tabular}
*** denotes $1 \%$ level of significance. JB-statistic determined that

Lags are selected by using SBC. In this table R show the numbers of co-integrating equation. $* * *$ indicates the null hypothesis rejection at $1 \%$ significance level. $* *$ indicates the null-hypothesis rejection at $5 \%$ significance level errors are distributed normally. $\mathrm{R}^{2}$ value is 0.995 which means that model is $99 \%$ good fit. The un-balanced and balanced panel in the long-run estimations is exposed in Table 5 through last two columns. The robustness of un-balanced panel co-integration tests is verified with the findings of Appendix B.

\subsection{The Panel Estimation in Long Run and Short Run} The presence of a co-integration association among the variables, the second step is to estimation of the long-run and short-run results of Equations.1 and 2. The long run estimation of the effect of output and energy consumption on $\mathrm{CO}_{2}$ emissions for all MMVT countries and for both balanced MMT and unbalanced MMVT are presented in Table 5. The errors were distributed normally for each of the six equations, as estimation with the JB statistics, wherever the autoregressive conditional heteroscedasticity GARCH model is employed to manage heteroscedasticity in the residuals for the equation of Thailand. Energy consumption results evaluated from Equation. (1) with Country specification are all above then unity and significant at $1 \%$. The effects range from 1.23 for Thailand and 1.55 for Vietnam. Real-GDP results are varied by the significant and positive values for Vietnam and Thailand, significant and negative values for Myanmar and insignificant for Malaysia. The GDP' ${ }^{2}$ results show significant and negative values for Vietnam and Thailand, significant and positive values for Myanmar and insignificant for Malaysia.

The panel results for each variable, declared in Table 5 in the last two columns indicate that each and every variable is significant at $1 \%$ level from Equation.1. The long run panel results For MMVT unbalanced panel data of $\mathrm{CO}_{2}$ emissions with appreciate to energy consumption, is more than then one (1.85), denotes that $1 \%$ raise in per-capita energy consumption leads per-capita raise in $\mathrm{CO}_{2}$ emissions through $1.85 \%$. The findings show that the turning point of the Environmental Kuznets Curve appears at a level of income $5.39(=1.35 / 0.25$, in logs $)$. These findings are in line with Apergis and Payne (2009) and Ang (2007), the estimated findings of the Environmental Kuznets Curve hypothesis are favorable for the level of $\mathrm{CO}_{2}$ emissions through income $1^{\text {st }}$ rise, stable, and after that decrease. Wagner (2008), estimated that an inverted U shaped linkage among GDP growth and $\mathrm{CO}_{2}$ emissions is not in long term significant. These results suggested that a very high

\begin{tabular}{|c|c|c|c|c|}
\hline & Malaysia & Myanmar & Vietnam & Thailand \\
\hline Intercept & $-46.59(-1.27)$ & $19.89 * *(2.39)$ & $-34.98 * * *(-10.21)$ & $-10.19 * * *(114.8)$ \\
\hline LEC & $1.31 * * *(3.68)$ & $1.39 * * *(29.60)$ & $1.55^{* * *}(3.99)$ & $1.23 * * *(77.6)$ \\
\hline LGDP & $9.56(1.07)$ & $-7.53 * * *(-3.46)$ & $8.47 * * *(5.09)$ & $0.88 * * *(245.8)$ \\
\hline LGDP $^{2}$ & $-0.60(-0.15)$ & $0.48 * * *(3.36)$ & $-0.69 * * *(-5.51)$ & $-0.06 * * *(-283.3)$ \\
\hline $\mathrm{R}^{2}$ & 0.87 & 0.99 & 0.99 & 0.99 \\
\hline JB & 1.63 & 1.58 & 0.007 & 0.16 \\
\hline p-value & 0.44 & 0.45 & 0.99 & 0.92 \\
\hline Panel (MMVT) & Panel (MMT) & & & \\
\hline$-15.18 * * *(-12.81)$ & $-17.37 * * *(-24.44)$ & & & \\
\hline $1.85 * * *(13.23)$ & $1.95 * * *(25.97)$ & & & \\
\hline $1.35 * * *(5.73)$ & $1.88 * * *(9.51)$ & & & \\
\hline$-0.12 * * *(-5.96)$ & $-0.16 * * *(-9.88)$ & & & \\
\hline 0.99 & 0.99 & & & \\
\hline 0.02 & 0.27 & & & \\
\hline 0.98 & 0.87 & & & \\
\hline
\end{tabular}

Table 5: $\mathrm{CO}_{2}$ emission long-run estimation

Figures in parenthesis denotes T-statistics and Z-statistics, appropriately. ${ }^{* * *}$ denotes $1 \%$ significance level. $* *$ denotes $5 \%$ significance level 
reactivity of $\mathrm{CO}_{2}$ emissions to variations in energy-consumption and real. GDP in long run.

The short run results found in Table 6 are estimated by Error-Correction-Model in Equation 2 for MMVT countries. Besides for Vietnam, the selected optimal lag is one, based on SBC, by normally distribution of errors as estimated by JB-statistic, the GARCH model $(2,0)$ is applied on Vietnam equation. $\mathrm{R}^{2}$ shows ranges from 0.65 for Vietnam to 0.76 for Malaysia.

The short run results values are lesser than the long-run values. The short-run finding shows that the coefficients on energy consumption are significant and positive at $1 \%$ level, besides for Vietnam its coefficients is insignificant and positive. The coefficients for real output is mostly statistically insignificant. The ECT estimated coefficient is significant and negative at $10 \%$ level or best for four MMVT countries. The value of the ECT is arrangements from disequilibrium to equilibrium. The ECT coefficient indicates that how much time required for variation from dis-equilibrium to come back to equilibrium. Thus, Myanmar can get as small as now more than nine-months(0.77years) (Myanmar) to come back on equilibrium, or as longer as 5.84years(Malaysia).

\subsection{Panel Causality-tests}

The presence of a long-run co-integration linkage amongst $\mathrm{CO}_{2}$ emissions, $G D P$, energy- consumption, and $G D P^{2}$ suggested that there should be minimum one direction granger causality. The causality test findings from Equation. 3 with the use of E-Views are shown in Table 7 used for MMVT countries. A 10\% level of significance is assumed in this paper. The short-run results suggest causal relation in unidirectional among $\mathrm{CO}_{2}$ emissions, energy-consumption and in real-output and here is bidirectional causal relation among energy-consumption and $\mathrm{CO}_{2}$ emissions. The Error-Correction-Term co-efficient are significant in GDP ${ }^{2}$ and energy-consumption. $\mathrm{CO}_{2}$ emissions and energy consumption in the long-run Granger cause real output and mutually $\mathrm{CO}_{2}$ emissions and real output Granger-cause energy consumption. The Granger endogeneity confirmed in all variables by joint WaldTest findings in columns 6,8 of Table 7 . The energy consumption significances result of interactional terms of vary, by the $\mathrm{CO}_{2}$ emissions, ECT and GDP equations recommend that, in the jointly short run and long run, energy-consumption is strong granger causes the $\mathrm{CO}_{2}$ emissions and output-growth. In a same way, findings suggested that $\mathrm{CO}_{2}$ emissions strong granger cause the energy-consumption and output-growth. This shows that when the shocks appear in organization, $\mathrm{CO}_{2}$ emissions and energyconsumption accept the trouble of adjustment in short run to reestablish equilibrium in long run. Though the GDP result is insignificant in interactive terms, by the ECT, $\mathrm{CO}_{2}$ emissions and energy-consumption equation it imply that here is no stronger granger causality as of output-growth to $\mathrm{CO}_{2}$ emissions and energy-consumption. Therefore, we can conclude that according

Table 6: $\mathrm{CO}_{2}$ emissions short run findings for all of the MMVT countries

\begin{tabular}{|c|c|c|c|c|}
\hline & Malaysia & Myanmar & Vietnam & Thailand \\
\hline Intercept & $-0.002(-0.41)$ & $-0.003(-0.45)$ & $0.02 * *(2.44)$ & $-0.01(-1.10)$ \\
\hline$\Delta \operatorname{LCO}(-1)$ & $0.42 * *(2.33)$ & $0.68 *(2.04)$ & $-0.41 * *(-2.08)$ & $0.22(1.09)$ \\
\hline$\triangle \mathrm{LEC}$ & $0.93 * * *(3.2)$ & $0.98 * * *(4.05)$ & $0.12(0.40)$ & $1.14 * * *(7.68)$ \\
\hline$\Delta \operatorname{LEC}(-1)$ & $-0.78 * *(-2.12)$ & $-0.86 *(-2.10)$ & $0.59 *(1.75)$ & $-0.04(-0.16)$ \\
\hline$\triangle \mathrm{LEC}(-2)$ & - & - & $0.64 * *(1.97)$ & - \\
\hline$\triangle \mathrm{LGDP}$ & $7.64(0.62)$ & $-1.33(-0.37)$ & $0.17(0.10)$ & $0.58(0.46)$ \\
\hline$\Delta \operatorname{LGDP}(-1)$ & $-6.73(-0.66)$ & $1.05(3.30)$ & - & $0.36(0.28)$ \\
\hline$\Delta \mathrm{LGDP}(-2)$ & - & - & $10.9 * * *(4.1)$ & - \\
\hline$\Delta \mathrm{LGDP}^{2}$ & $-0.44(-0.55)$ & $0.08(0.36)$ & $0.02(0.18)$ & $-0.02(-0.22)$ \\
\hline$\Delta \operatorname{LGDP}^{2}(-1)$ & $0.42(0.67)$ & $-0.05(-0.24)$ & - & $-0.04(0.34)$ \\
\hline$\Delta \mathrm{LGDP}^{2}(-2)$ & - & - & $-0.99 * * *(-4.2)-$ & \\
\hline $\operatorname{ECT}(-1)$ & $-0.17 *(-1.98)$ & $-1.29 * *(-2.82)$ & $-0.28 * *(2.44)$ & $-0.80 * * *(-3.13)$ \\
\hline $\mathrm{R}^{2}$ & 0.76 & 0.98 & 0.65 & 0.86 \\
\hline P-value & 0.71 & 0.77 & 0.24 & 0.50 \\
\hline $\mathrm{JB}$ & 0.66 & 0.51 & 2.79 & 1.35 \\
\hline \multicolumn{5}{|c|}{ Short run elasticities } \\
\hline LGDP & 0.90-0.03GDP & $-0.28+0.05 \mathrm{GDP}$ & 12.17-1.9GDP*** & 0.95-0.13GDP \\
\hline LEC & $0.154 * * *$ & $0.116^{* * *}$ & 1.37 & $1.10 * * *$ \\
\hline Adjustment (years) & 4.84 & 0.77 & 4.53 & 2.24 \\
\hline
\end{tabular}

Figures in brackets denotes that t-statistics and z-statistics, appropriately. $* *$ denotes $1 \%$ significance level. $* *$ denotes $5 \%$ significance level. $*$ denotes $10 \%$ significance level

Table 7: Findings of un-balanced panel-tests of causality for MMVT countries

\begin{tabular}{|c|c|c|c|c|c|c|c|c|}
\hline \multirow[t]{3}{*}{ Dep. var. } & \multicolumn{8}{|c|}{ Causation of independent variables } \\
\hline & \multicolumn{3}{|c|}{ Short run } & Long run & \multicolumn{3}{|c|}{ (short run/long run) } & \multirow[t]{2}{*}{$\mathbf{R}^{2}$} \\
\hline & $\begin{array}{c}\Delta \mathrm{LCO} \\
\text { F-statistics }\end{array}$ & $\Delta \mathbf{L E C}$ & $\begin{array}{c}\Delta \text { LGDP and } \\
\Delta \text { LGDP }^{2}\end{array}$ & $\begin{array}{c}\text { ECT } \\
\text { t-statistics }\end{array}$ & $\begin{array}{c}\Delta \text { LCO,ECT } \\
\text { F-statistics }\end{array}$ & $\triangle \mathrm{LEC}, \mathrm{ECT}$ & $\begin{array}{c}\Delta \mathrm{LGDP} \text { and } \\
\Delta \mathrm{LGDP}^{2}, \mathrm{ECT}\end{array}$ & \\
\hline$\triangle \mathrm{LCO}$ & & $6.96(+)^{* * *}$ & 1.09 & -0.16 & & $3.60 * *$ & 1.41 & 0.72 \\
\hline$\triangle \mathrm{LEC}$ & $1.69(+)^{*}$ & & 2.01 & $1.89 *$ & $4.60 * *$ & & 1.69 & 0.87 \\
\hline$\Delta \mathrm{LGDP}$ & $6.28(-)^{* * *}$ & $8.60(+)^{* * *}$ & & -1.57 & $6.27 * * *$ & $7.45^{* * *}$ & & 0.84 \\
\hline$\Delta \mathrm{LGDP}^{2}$ & $5.31(-)^{* *}$ & $7.83(+)^{* * *}$ & & $-2.03 * *$ & $5.52 * * *$ & $7.17 * * *$ & & 0.80 \\
\hline
\end{tabular}

The lag selection is base on SBC. *denotes $10 \%$ significance level, **denotes $5 \%$ significance level, ***denotes $1 \%$ significance level 
to the overall results,: (1) here is a bi-directional stronger Granger-causality in energy consumption and $\mathrm{CO}_{2}$ emissions; (2) here exists bi-directional long-run relation between energy consumption and real output, although here is a causal relation between energy consumption to real- output in short run; (3) here exists stronger causal relation from $\mathrm{CO}_{2}$ emissions to real output and the effect of $\mathrm{CO}_{2}$ emissions on real output is significant and negative. The results of unbalanced panel causality testes in robustness are verified with the findings of Appendix C.

\section{DISCUSSIONS AND POLICES}

The study investigates a long-run equilibrium relation among $\mathrm{CO}_{2}$ emissions, energy consumption and real-output used for the MMVT countries panel. The policy-makers must be known of panel evaluated elasticities of energy-consumption and real output, are significant at $1 \%$-level in the long term, however highlight the value of these two variables in serving to give details on $\mathrm{CO}_{2}$ emissions.

During the long-run from $\mathrm{CO}_{2}$ emissions to output the results of causality are favorable of $\mathrm{CO}_{2}$ emissions energy-consumption and output energy-consumption in bi-directional causal relation and as well as uni-directional causal relation. These findings pose main issues for policymakers to MMVT countries. The Granger causality in bidirectional results among energy-consumption and real output indicates that energy-consumption and economic-growth are jointly estimated. These developing nations are energy dependent nations, in a panel. This result is same as to the results of Ang (2008), Oh and Lee (2004), Mahadevan and Asafu-Adjaye (2007), Apergis and Payne (2009). The economic growth in low level brings to energy demand in low level and economic growth in high level brings to energy demand in high level. The estimation also indicates that energy consumption and $\mathrm{CO}_{2}$ emissions accept the trouble of the short-term adjustments to reestablish long term equilibrium level. Therefore the economic growth may restrain by shortage of energy consumption infrastructure. Industries productions such as transportation, construction and manufacturing, demands a large quantity of energy-infrastructure. Increase in real GDP required huge energy-consumption. The policies for energy consumption that plan at decrease energy use exclusive of moving the end use advantages should relatively find-out ways of decreasing consumer demand.

The estimated results of strong bidirectional Granger causal relation between energy consumption and $\mathrm{CO}_{2}$ emissions shows that energy consumption increase leads to emissions increase, particularly in the fossil fuel consumption. Therefore, policies appear to be a dynamic way to reduce $\mathrm{CO}_{2}$ emissions with decreasing demand for energy in MMVT countries. The results of bidirectional causality of $\mathrm{CO}_{2}$ emissions energy-consumption is in line by the experiential finding of Halicioglu (2009), although contradict from that of (Zhang and Cheng 2009).

In addition essential finding is that the sum up of the coefficients lag on $\mathrm{CO}_{2}$ emissions is negative and $\mathrm{CO}_{2}$ emissions strongly Granger-cause real-output, however the inverse is cannot accurate. These results suggests that environment degradation has a causative effect on economic growth, and a consistence decrease in value of environment can strive a negative externality to the economy throughout effect on human health, and also decrease production in long run. The reduction in emissions pollutant, the perfect level of pollutants in environment that it creates and imported through industries and areas must be estimated for all countries, and solutions are depend on market in the type of taxes pollutant could reduce the volume of this trouble Halicioglu (2009). The causality empirical results outline is in line with Ang (2008), but contradict by Halicioglu (2009), Ang (2007), Apergis and Payne (2009). In conclusion, demands of energy decreasing, efficiency energy increasing and energy supply investment could be activated by never harmful effect on the MMVT countries economic growth and it could be decrease $\mathrm{CO}_{2}$ emissions. In the similar time period, motivate industries to take up new technologies to reduce pollution with the intention to stand by way of the guidelines of the postkyoto-protocol.

\section{CONCLUDING REMARKS}

This study is an attempt to analyze the determining-factors of $\mathrm{CO}_{2}$ emissions with the four Asian (MMVT) countries and using data over the period 1971-2005, excluding for Vietnam (1990-2005). The estimation of $\mathrm{CO}_{2}$ emissions and to explore the sensitivity problems of energy consumption and real-output in long-run and short-run the Panel cointegration techniques were applied. The ECM was use to attain the short run results for all countries. The multi-variate Vector Error Correction model was applied to confine the un-balanced panel dynamic relations between the variables.

The analysis of results discovered definite properties of MMVT countries $\mathrm{CO}_{2}$ emissions. First the estimation finding out the equilibrium in long-run relation among, $\mathrm{CO}_{2}$ emissions energy consumption and real-output for MMVT, countries. Second, the energy consumption in long-run is significant and computed to be higher than one for four countries of MMVT. These results recommend that responsiveness of higher energy consumption to variations in $\mathrm{CO}_{2}$ emissions. Third, the real-output for four of the MMVT countries shows an inverse U-shape significant relation. The estimated findings are supported of the Environmental Kuznets Curve hypothesis; $\mathrm{CO}_{2}$ emissions first increase, stabilize and then decrease with real-output. Therefore a real-output increase essentially $\mathrm{CO}_{2}$ emissions decrease while the environmental demand for value increase and such economies growing. Fourth, the short-term energy consumption has significant effect for three countries and positive effect for each of the four MMVT countries. Real-output results are mostly in-significant in Short-run. The results show that response of emission to both real output and energy consumption could be large in the long time then inside the short term.

The better policy implication for energy consumption and economic growth is to raise effectiveness of energy and supply outlay and to set up energy-consumption policies to decrease inessential wasted of energy. Generally, through the development and approach of economic-background in 4 Asian (MMVT) countries, for energy-dependent developing country the environmental policy should be applicable. 


\section{REFERENCES}

Abidin, I.S.Z., Haseeb, M., Azam, M., Islam, R. (2015), Foreign direct investment, financial development, international trade and energy consumption: Panel data evidence from selected ASEAN countries. International Journal of Energy Economics and Policy, 5(3), 841-850.

Adom, P.K. (2011), Electricity consumption-economic growth nexus: The Ghanaian case. International Journal of Energy Economics and Policy, 1(1), 18-31.

Al-Iriani, M.A. (2006), Energy GDP relationship revisited: An example from GCC countries using panel causality. Energy Policy, 34(17), 3342-3350.

Al Mamun, M., Sohag, K., Mia, M.A.H., Uddin, G.S., Ozturk, I. (2014), Regional differences in the dynamic linkage between $\mathrm{CO}_{2}$ emissions, sectoral output and economic growth. Renewable and Sustainable Energy Reviews, 38, 1-11.

Alam, M.J., Begum, I.A., Buysse, J., Van Huylenbroeck, G. (2012), Energy consumption, carbon emissions and economic growth nexus in Bangladesh: Cointegration and dynamic causality analysis. Energy Policy, 45, 217-225.

Alam, M.M., Murad, M.W., Noman, A.H.M., Ozturk, I. (2016), Relationships among carbon emissions, economic growth, energy consumption and population growth: Testing environmental Kuznets curve hypothesis for Brazil, China, India and Indonesia. Ecological Indicators, 70, 466-479.

Alves, D.C., da Silveira Bueno, D.L. (2003), Short-run, long-run and cross elasticities of gasoline demand in Brazil. Energy Economics, 25(2), 191-199.

Ang, J.B. (2007), $\mathrm{CO}_{2}$ emissions, energy consumption, and output in France. Energy Policy, 35(10), 4772-4778.

Ang, J.B. (2008), Economic development, pollutant emissions and energy consumption in Malaysia. Journal of Policy Modeling, 30(2), 271-278.

Apergis, N., Payne, J.E. (2009), $\mathrm{CO}_{2}$ emissions, energy usage, and output in central America. Energy Policy, 37(8), 3282-3286.

Asafu-Adjaye, J. (2000), The relationship between energy consumption, energy prices and economic growth: Time series evidence from Asian developing countries. Energy Economics, 22(6), 615-625.

Bank, W. (2007), Growth and $\mathrm{CO}_{2}$ Emissions: How Do Different Countries Fare, Environment Department. Washington, DC: World Bank.

Bank, W. (2017), World Bank Country and Lending Groups, World Bank Data Help Desk Washington, DC: World Bank.

Bari, N.A.A., Yusuff, R., Ismail, N., Jaapar, A., Ahmad, R. (2012), Factors influencing the construction cost of industrialised building system (IBS) projects. Procedia Social and Behavioral Sciences, 35, 689-696.

Belloumi, M. (2009), Energy consumption and GDP in Tunisia: Cointegration and causality analysis. Energy Policy, 37(7), 2745-2753.

Breitung, J. (2001), The Local Power of Some Unit Root Tests for Panel Data. Nonstationary Panels, Panel Cointegration, and Dynamic Panels. Bingley: Emerald Group Publishing Limited. p161-177.

Choi, I. (2001), Unit root tests for panel data. Journal of International Money and Finance, 20(2), 249-272.

Coondoo, D., Dinda, S. (2008), Carbon dioxide emission and income: A temporal analysis of cross-country distributional patterns. Ecological Economics, 65(2), 375-385.

Dahmardeh, N., Mahmoodi, M., Mahmoodi, E. (2012), Energy consumption and economic growth: Evidence from 10 Asian developing countries. Journal of Basic and Applied Scientific Research, 2(2), 1385-1390.

Dantama, Y.U., Abdullahi, Y.Z., Inuwa, N. (2012), Energy consumptioneconomic growth nexus in Nigeria: An empirical assessment based on ARDL bound test approach. European Scientific Journal, 8(12), 234-244.

Dinda, S. (2004), Environmental Kuznets curve hypothesis: A survey.
Ecological Economics, 49(4), 431-455.

Dinda, S., Coondoo, D. (2006), Income and emission: A panel data-based cointegration analysis. Ecological Economics, 57(2), 167-181.

Engle, R.F., Granger, C.W. (1987), Co-integration and error correction: Representation, estimation, and testing. Econometrica: Journal of the Econometric Society, 55, 251-276.

Finley, M. (2012), The oil market to 2030 implications for investment and policy. Economics of Energy and Environmental Policy, 1(1), 25-36.

Friedl, B., Getzner, M. (2003), Determinants of $\mathrm{CO}_{2}$ emissions in a small open economy. Ecological Economics, 45(1), 133-148.

Grossman, G.M., Krueger, A.B. (1991), Environmental Impacts of a North American Free Trade Agreement. National Bureau of Economic Research. Working Paper.

Halicioglu, F. (2009), An econometric study of $\mathrm{CO}_{2}$ emissions, energy consumption, income and foreign trade in Turkey. Energy Policy, 37(3), 1156-1164.

Hwang, J.H., Yoo, S.H. (2014), Energy consumption, $\mathrm{CO}_{2}$ emissions, and economic growth: Evidence from Indonesia. Quality and Quantity, 48(1), 63-73.

Im, K.S., Pesaran, M.H., Shin, Y. (2003), Testing for unit roots in heterogeneous panels. Journal of Econometrics, 115(1), 53-74.

Islam, M.R., Saidur, R., Rahim, N.A., Solangi, K.H. (2009), Renewable energy research in Malaysia. Engineering e-Transaction, 4(2), 69-72.

Jarque, C.M., Bera, A.K. (1980), Efficient tests for normality, homoscedasticity and serial independence of regression residuals. Economics Letters, 6(3), 255-259.

Johansen, S., Juselius, K. (1990), Maximum likelihood estimation and inference on cointegration with applications to the demand for money. Oxford Bulletin of Economics and Statistics, 52(2), 169-210.

Jumbe, C.B. (2004), Cointegration and causality between electricity consumption and GDP: Empirical evidence from Malawi. Energy Economics, 26(1), 61-68.

Kao, C. (1999), Spurious regression and residual-based tests for cointegration in panel data. Journal of Econometrics, 90(1), 1-44.

Keppler, J.H., Mansanet-Bataller, M. (2010), Causalities between $\mathrm{CO}_{2}$, electricity, and other energy variables during phase I and phase II of the EU ETS. Energy Policy, 38(7), 3329-3341.

Kim, S.W., Lee, K., Nam, K. (2010), The relationship between $\mathrm{CO}_{2}$ emissions and economic growth: The case of Korea with nonlinear evidence. Energy Policy, 38(10), 5938-5946.

Kraft, J., Kraft, A. (1978), On the relationship between energy and GNP. The Journal of Energy and Development, 16, 401-403.

Lau, E., Chye, X.H., Choong, C.K. (2011), Energy-growth causality: Asian countries revisited. International Journal of Energy Economics and Policy, 1(4), 140-149.

Lean, H.H., Smyth, R. (2014), Are shocks to disaggregated energy consumption in Malaysia permanent or temporary? Evidence from LM unit root tests with structural breaks. Renewable and Sustainable Energy Reviews, 31, 319-328.

Lean, H.H., Smyth, R. (2014), Disaggregated energy demand by fuel type and economic growth in Malaysia. Applied Energy, 132, 168-177.

Lee, C.C., Lee, J.D. (2009), Income and $\mathrm{CO}_{2}$ emissions: Evidence from panel unit root and cointegration tests. Energy Policy, 37(2), 413-423.

Levin, A., Lin, C.F., Chu, C.S.J. (2002), Unit root tests in panel data: Asymptotic and finite-sample properties. Journal of Econometrics, 108(1), 1-24.

Maddala, G.S., Wu, S. (1999), A comparative study of unit root tests with panel data and a new simple test. Oxford Bulletin of Economics and Statistics, 61(S1), 631-652.

Magazzino, C. (2014), A panel VAR approach of the relationship among economic growth, $\mathrm{CO}_{2}$ emissions, and energy use in the ASEAN-6 countries. International Journal of Energy Economics and Policy, 4(4), 546-553. 
Mahadevan, R., Asafu-Adjaye, J. (2007), Energy consumption, economic growth and prices: A reassessment using panel VECM for developed and developing countries. Energy Policy 35(4), 2481-2490.

Managi, S., Jena, P.R. (2008), Environmental productivity and Kuznets curve in India. Ecological Economics, 65(2), 432-440.

Martínez-Zarzoso, I., Bengochea-Morancho, A. (2004), Pooled mean group estimation of an environmental Kuznets curve for $\mathrm{CO}_{2}$. Economics Letters, 82(1), 121-126.

Masih, A.M., Masih, R. (1996), Energy consumption, real income and temporal causality: Results from a multi-country study based on cointegration and error-correction modelling techniques. Energy Economics, 18(3), 165-183.

Mehrara, M. (2007), Energy consumption and economic growth: The case of oil exporting countries. Energy Policy, 35(5), 2939-2945.

Menyah, K., Wolde-Rufael, Y. (2010), Energy consumption, pollutant emissions and economic growth in South Africa. Energy Economics, 32(6), 1374-1382.

Morimoto, R., Hope, C. (2004), The impact of electricity supply on economic growth in Sri Lanka. Energy Economics, 26(1), 77-85.

Narayan, P.K., Seema, N., Arit, P. (2008), A structural VAR analysis of electricity consumption and real GDP: Evidence from the G7 countries. Energy Policy, 36(7), 2765-2769.

Narayan, P.K., Prasad, A. (2008), Electricity consumption real GDP causality nexus: Evidence from a bootstrapped causality test for 30 OECD countries. Energy Policy, 36(2), 910-918.

Oh, T.H., Yee, P.S., Chua, S.C. (2010), Energy policy and alternative energy in Malaysia: Issues and challenges for sustainable growth. Renewable and Sustainable Energy Reviews, 14(4), 1241-1252.

Oh, W., Lee, K. (2004), Energy consumption and economic growth in Korea: Testing the causality relation. Journal of Policy Modeling, 26(8-9), 973-981.

Oxley, L., Greasley, D. (1998), Vector autoregression, cointegration and causality: Testing for causes of the British industrial revolution. Applied Economics, 30(10), 1387-1397.

Ozturk, I., Acaravci, A. (2010), $\mathrm{CO}_{2}$ emissions, energy consumption and economic growth in Turkey. Renewable and Sustainable Energy Reviews, 14(9), 3220-3225.

Ozturk, I., Acaravci, A. (2013), The long-run and causal analysis of energy, growth, openness and financial development on carbon emissions in Turkey. Energy Economics, 36, 262-267.

Ozturk, I., Aslan, A., Kalyoncu, H. (2010), Energy consumption and economic growth relationship: Evidence from panel data for low and middle income countries. Energy Policy, 38(8), 4422-4428.

Pao, H.T. (2009), Forecast of electricity consumption and economic growth in Taiwan by state space modeling. Energy, 34(11), 1779-1791.

Pao, H.T., Tsai, C.M. (2011), Modeling and forecasting the $\mathrm{CO}_{2}$ emissions, energy consumption, and economic growth in Brazil. Energy 36(5), 2450-2458.

Pao, H.T., Tsai, C.M. (2011), Multivariate granger causality between $\mathrm{CO}_{2}$ emissions, energy consumption, FDI (foreign direct investment) and GDP (gross domestic product): Evidence from a panel of BRIC (Brazil, Russian Federation, India, and China) countries. Energy,
36(1), 685-693.

Paul, S., Bhattacharya, R.N. (2004), Causality between energy consumption and economic growth in India: A note on conflicting results. Energy Economics, 26(6), 977-983.

Pedroni, P. (1999), Critical values for cointegration tests in heterogeneous panels with multiple regressors. Oxford Bulletin of Economics and Statistics, 61(S1), 653-670.

Pedroni, P. (2004), Panel cointegration: Asymptotic and finite sample properties of pooled time series tests with an application to the PPP hypothesis. Econometric Theory, 20(3), 597-625.

Phillips, P.C., Perron, P. (1988), Testing for a unit root in time series regression. Biometrika, 75(2), 335-346.

Rezitis, A.N., Ahammad, S. (2015), The relationship between energy consumption and economic growth in south and Southeast Asian countries: A panel VAR approach and causality analysis. International Journal of Energy Economics and Policy, 5, 704-715.

Shahbaz, M., Lean, H.H., Shabbir, M.S. (2012), Environmental Kuznets curve hypothesis in Pakistan: Cointegration and Granger causality. Renewable and Sustainable Energy Reviews, 16(5), 2947-2953.

Shiu, A., Lam, P.L. (2004), Electricity consumption and economic growth in China. Energy Policy, 32(1), 47-54.

Soytas, U., Sari, R., Ewing, B.T. (2007), Energy consumption, income, and carbon emissions in the United States. Ecological Economics, 62(3-4), 482-489.

Stern, D.I. (2004), The rise and fall of the environmental Kuznets curve. World Development, 32(8), 1419-1439.

Stern, D.I. (2011), The role of energy in economic growth. Annals of the New York Academy of Sciences, 1219(1), 26-51.

Toda, H.Y., Yamamoto, T. (1995), Statistical inference in vector autoregressions with possibly integrated processes. Journal of Econometrics, 66(1-2), 225-250.

Wagner, M. (2008), The carbon Kuznets curve: A cloudy picture emitted by bad econometrics? Resource and Energy Economics, 30(3), 388-408.

Xue, B., Geng, Y., Muller, K., Lu, C., Ren, W. (2014), Understanding the causality between carbon dioxide emission, fossil energy consumption and economic growth in developed countries: An empirical study. Sustainability, 6(2), 1037-1045.

Yoo, S.H. (2005), Electricity consumption and economic growth: Evidence from Korea. Energy Policy, 33(12), 1627-1632.

Yuan, J., Zhao, C., Yu, S., Hu, Z. (2007), Electricity consumption and economic growth in China: Cointegration and co-feature analysis. Energy Economics, 29(6), 1179-1191.

Yusoff, N.Y.B., Bekhet, H.A. (2016), Impacts of energy subsidy reforms on the industrial energy structures in the Malaysian economy: A computable general equilibrium approach. International Journal of Energy Economics and Policy, 6(1), 88-97.

Zapata, H.O., Rambaldi, A.N. (1997), Monte Carlo evidence on cointegration and causation. Oxford Bulletin of Economics and Statistics, 59(2), 285-298.

Zhang, X.P., Cheng, X.M. (2009), Energy consumption, carbon emissions, and economic growth in China. Ecological Economics, 68(10), 2706-2712. 


\section{APPENDIX}

Table A1: Appendix A. Balanced panel of unit root tests for MMT countries

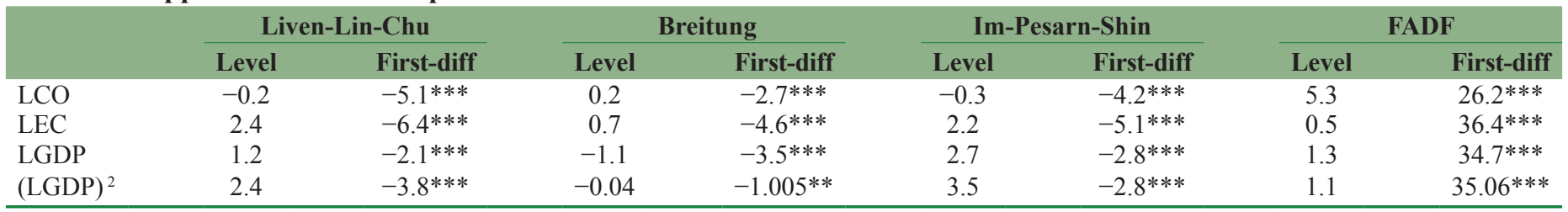

The lag selection is base on SBC. $* * *$ indicates the null-hypothesis rejection at $1 \%$ levels. $* *$ indicates the null-hypothesis rejection at $5 \%$ levels

Table B1: Appendix B. Balanced panel of co-integration tests for MMT countries

\begin{tabular}{lcc} 
& Pedrono test & Statistics \\
Test statistics & & -0.36 \\
Panel $\rho$-stat. (weighted statistic) & -0.07 \\
Panel v-stat. (weighted statistic) & $-2.75^{* * *}$ \\
Panel ADF-stat. (weighted statistic) & $-1.20^{* *}$ & $-4.11^{* * *}$ \\
Panel PP-stat. (weighted statistic) & -0.61 \\
Group PP-stat. & & $-5.38^{* * *}$ \\
Group $\rho$-stat. & & $-3.66(0.000)^{* * *}$ \\
Group ADF-stat & Johansen Fisher test & \\
Kao test & Maximum-eigenvalue & Tracevalue \\
ADF-stat & $38.5(0.000)^{* * *}$ & $46.5(0.000)^{* * *}$ \\
& $12.7(0.06)^{* *}$ & $15.1(0.02)^{* *}$ \\
Null-hypothesis & $9.3(0.21)$ & $5.9(0.32)$ \\
$\mathrm{R}=0$ & $2.7(0.93)$ & $2.7(0.9)$ \\
$\mathrm{R} \leq 1$ & & \\
$\mathrm{R} \leq 2$ & & \\
$\mathrm{R} \leq 3$ & & \\
\hline
\end{tabular}

The lag selection is base on SBC. R indicates the cointegratinon equation. ***denotes the null hypothesis rejection at $1 \%$ level. **denotes the rejection of null hypothesis at $5 \%$ level.

*denotes the rejection of null hypothesis at $5 \%$ level

Table C1: Appendix C. Balanced panel of causality tests for MMT countries

\begin{tabular}{|c|c|c|c|c|c|c|c|c|}
\hline \multirow[t]{3}{*}{ Dep var. } & \multicolumn{8}{|c|}{ Causation of independent variables } \\
\hline & \multicolumn{3}{|c|}{ Short run } & \multirow{2}{*}{$\begin{array}{c}\text { Long run } \\
\text { ECT } \\
\text { t-statistics }\end{array}$} & \multicolumn{3}{|c|}{ (Short run and long run) } & \multirow[t]{2}{*}{$\mathbf{R}^{2}$} \\
\hline & $\begin{array}{c}\Delta \mathrm{LCO} \\
\text { Fstatistics }\end{array}$ & $\Delta \mathbf{L E C}$ & $\begin{array}{c}\Delta \mathrm{LGDP} \\
\text { and } \Delta \mathbf{L G D P}^{2}\end{array}$ & & $\begin{array}{c}\Delta \mathrm{LCO}, \mathbf{E C T} \\
\text { F-statistics }\end{array}$ & $\begin{array}{c}\triangle \mathrm{LEC} \\
\text { ECT }\end{array}$ & $\begin{array}{c}\Delta \mathrm{LGDP} \text { and } \\
\Delta \mathbf{L G D P}^{2}, \mathbf{E C T}\end{array}$ & \\
\hline$\Delta \mathrm{LCO}$ & & $9.73(+)^{* * *}$ & 1.42 & 0.06 & & $5.45^{* * *}$ & 1.30 & 0.73 \\
\hline$\triangle \mathrm{LEC}$ & $0.15(-)^{*}$ & & 0.32 & $2.66 * *$ & $3.66 * *$ & & $3.8^{* *}$ & 0.83 \\
\hline$\Delta \mathrm{LGDP}$ & $10.27(-)^{* * *}$ & $20.26(+)^{* * *}$ & & -0.92 & $8.41 * * *$ & $14.09 * * *$ & & 0.74 \\
\hline$\Delta \mathrm{LGDP}^{2}$ & $46.13(-) * * *$ & $122.20(+)^{* * *}$ & & $-4.31 * * *$ & $23.70 * * *$ & $62.43 * * *$ & & 0.90 \\
\hline
\end{tabular}

The lags are selected using SBC. $* *$ denotes significance level at $5 \%$ level. $* * *$ denotes significance level at $1 \%$ level 